CATALLAXY

Volume 2 Issue 1 June 2017

e-ISSN 2544-090X

ऽwww.catallaxy.pl

Oryginalny artykut naukowy

otrzymano: 16.05.2017 / zaakceptowano: 28.06.2017 / opublikowano online: 30.06 .2017

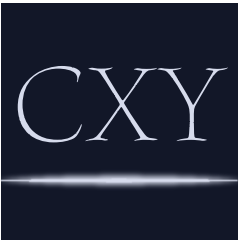

(๑) $\odot$

Wiśniewska, A. (2017). Waluty wirtualne w kontekście teorematu regresji Ludwiga von Misesa. Catallaxy, 2(1): 37-45. doi:10.24136/cxy:2i1.4.

\title{
Waluty wirtualne w kontekście teorematu regresji Ludwiga von Misesa
}

\author{
ANNA WIŚNIEWSKA \\ Wydziat Nauk Ekonomicznych i Zarzadzania, Uniwersytet Mikotaja Kopernika w Toruniu, ul. Gagarina 13a, 87-100 \\ Torun, Polska \\ 曰amw@doktorant.umk.pl \\ (iD) orcid.org/0000-0002-0512-4550
}

\begin{abstract}
Abstrakt
Motywacja: Dynamiczny rozwój rynku walut wirtualnych, zapoczątkowany przez powstanie bitcoina, stawia przed teoretykami ekonomii wiele wyzwań. Jednym z problemów przez nich podnoszonych jest kwestia spełniania przez waluty wirtualne teorematu regresji. Problem ten jest główną przeszkodą w uznaniu określonych walut wirtualnych za pieniądz. Dotychczasowe badania w tym zakresie obejmują prawie wyłącznie bitcoina i jedynie sygnalizują problem przy okazji innych rozważań.

Cel: Celem artykułu jest odpowiedź na pytanie, czy i w jakim stopniu waluty wirtualne spełniają teoremat regresji L. von Misesa.

Wyniki: W artykule przyjęto założenie, że te kryptowaluty, powstałe w ramach projektów, których nie były bezpośrednim celem, mają większe szanse na posiadanie wartości niepieniężnej niż te, których wykreowanie było głównym celem projektu, tzn. takie, które miały za zadanie stać się pieniądzem. Przeprowadzona analiza studiów przypadku trzech kryptowalut: bitcoin, ether oraz factoid wykazała, że określenie wartości niepieniężnej poszczególnych walut wirtualnych, nie zawsze jest możliwe oraz zasadne. W przypadku bitcoina można uznać, że nie narusza on teorematu regresji, a wręcz posiada wiele cech niepieniężnych. Pozostałe dwie kryptowaluty, jak dotąd, nie pełnią funkcji płatniczej poza projektem, w ramach którego powstały.
\end{abstract}

Stowa kluczowe: bitcoin; waluty wirtualne; teoremat regresji JEL: B13; E49; G19

\section{Wprowadzenie}

Dynamiczny rozwój rynku walut wirtualnych, zapoczątkowany przez powstanie bitcoina, stawia przed teoretykami ekonomii wiele wyzwań. Dotyczą one nie tylko problemów natury praktycznej, czyli ewentualnej regulacji, opodatkowania, czy też zapobiegania wykorzystywaniu kryptowalut do działań niezgodnych $z$ obowiązującym prawem.
Równie intrygujące jest przeanalizowanie funkcjonowania walut wirtualnych $\mathrm{w}$ kontekście istniejących teorii pieniądza. Jednym $z$ takich problemów jest kwestia spełniania przez bitcoina, oraz inne waluty wirtualne, teorematu regresji L. von Misesa. Co ważne, dotychczasowe badania $\mathrm{w}$ tym zakresie są niewystarczające i skoncentrowane niemal wyłącznie na bitcoinie. Brakuje też opracowań poświęconych w całości walutom wirtualnym 
w kontekście teorematu regresji, zwykle problem ten jest sygnalizowany przy okazji innych rozważań.

Znalezienie satysfakcjonującego rozwiązania tej kwestii może stać się punktem wyjścia dla kolejnych rozważań dotyczących uznania poszczególnych walut wirtualnych za pieniądz. Mimo, że część z nich znajduje zastosowanie jako środek płatniczy, odpowiedź nie jest, jak dotąd, jednoznaczna.

Należy zwrócić uwagę na fakt, że poznanie i przeanalizowanie funkcjonowania ponad 700 walut wirtualnych, obecnych na rynku, jest zadaniem trudnym i czasochłonnym. Ponadto, wiele $z$ nich nie stanowi trwałych bytów. Na miejscu tych, które nie przetrwały na rynku, pojawiają się kolejne. Dlatego, w niniejszym artykule zdecydowano się na zastosowanie metody studium przypadku. Dotyczy ona, poza bitcoinem, dwóch walut wirtualnych, które według danych z portalu CoinMarketCap (2017), zajmują czołowe pozycje pod względem udziału w całkowitym wolumenie transakcji, a przy tym reprezentują interesujące projekty. Oznacza to, że ich powstanie nie miało na celu jedynie stworzenia kolejnej kryptowaluty.

Celem artykułu jest odpowiedź na pytanie, czy i w jakim stopniu waluty wirtualne spełniają teoremat regresji L. von Misesa. Realizacji celu przyporządkowano dwa pytania badawcze: (1) jak problem teorematu regresji w przypadku walut wirtualnych był dotychczas przedstawiany w literaturze? (2) co może stanowić niepieniężną wartość poszczególnych walut wirtualnych i czy można w ogóle ją określić?

W Sekcji 2., poświęconej przeglądowi literatury, zawarto klasyfikację walut wirtualnych, przedstawiono najważniejsze zagadnienia dotyczące teorematu regresji oraz dotychczasowe rozważania ekonomistów na temat problemu spełniania teorematu regresji przez waluty wirtualne. W Sekcji 3. określono metodę badawczą wraz ze wskazaniem jej ograniczeń. Wyniki badania, obejmującego studium przypadku trzech kryptowalut (bitcoin, ether, factoid) zostały opisane w Sek- cji 4. Sekcję 5. przeznaczono na podsumowanie rozważań podjętych $w$ artykule.

\section{Przegląd literatury}

Zanim zostaną przedstawione wyniki rozważań ekonomistów dotyczące problemu spełniania teorematu regresji przez waluty wirtualne, oba zagadnienia omówiono oddzielnie. Funkcjonowanie walut wirtualnych jest zjawiskiem stosunkowo nowym. Bitcoin, jako pierwsza kryptowaluta, stworzony został przez osobę (albo grupę osób) o pseudonimie Satoshi Nakamoto w 2009 roku (Sieroń, 2013, s. 31). Tożsamość twórcy pozostaje nieznana. W 2017 roku, na rynku obecnych było już ponad 700 walut wirtualnych, z których większość powstawała, aby powtórzyć sukces pioniera.

Zgodnie definicją przedstawioną przez Financial Action Task Force (FATF, 2014, s. 4), waluta wirtualna to: cyfrowy odpowiednik wartości, który można sprzedawać i kupować w cyberprzestrzeni funkcjonujący jako:

- środek wymiany;

- i/lub jednostka rozrachunkowa;

- i/lub środek tezauryzacji;

ale nie będący uregulowany prawnie. Warto zaznaczyć, że definicja ta jest bardzo szeroka, stąd Europejski Bank Centralny (EBC, 2012, s. 16), zaproponował następującą klasyfikację walut wirtualnych:

- zamknięte (niewymienialne);

- ojednokierunkowym przepływie środków (mogą być nabyte za tradycyjny pieniądz, ale nie mogą być na niego wymienione);

- o dwukierunkowym przepływie środków (wymienialne).

Jeśli dana waluta wirtualna charakteryzuje się dwukierunkowym przepływem środków i dodatkowo została zaprojektowana w oparciu o zasady kryptografii, w literaturze określana jest mianem kryptowaluty (FATF, 2014, s. 5).

\subsection{Teoremat regresji}

Teoremat regresji został po raz pierwszy przedstawiony w dziele L. von Misesa pt. The- 
orie des Geldes und der Umlaufsmittel z 1912 roku. Zgodnie z nim, dzisiejsza wartość pieniądza jest determinowana przez jego wczorajszą wartość. Dokładniej rzecz ujmując: dzisiejszy wolumen popytu na pieniądz jest wynikiem jego wartości $z$ dnia poprzedniego. Implikuje to możliwość prześledzenia historii pieniądza, aż do momentu, gdy miał on podwójne zastosowanie: zarówno pieniężne, jak i niepieniężne. Nie można więc uznać za pieniądz towaru, który, w momencie rozpoczęcia pełnienia jego funkcji, nie miał wartości bazującej na zastosowaniu niepieniężnym (Mises, 1954, ss. 108-114).

P. Surda $(2014$, s. 2), wskazał na brak zgody wśród ekonomistów dotyczącej definicji pojęcia „wartość niepieniężna”. Problem ten dodatkowo utrudnia rozpatrywanie walut wirtualnych w kontekście teorematu regresji.

Co więcej, należy zwrócić uwagę na fakt, że nie wszyscy przedstawiciele szkoły austriackiej uwzględniali teoremat regresji w swoich rozważaniach o pieniądzu i jego powstawaniu. M.N. Rothbard (2011, s. 4), skrytykowal idee wolnej bankowości, a konkretnie swobodę emisji własnych walut, stworzoną przez F.A. von Hayeka, gdyż pieniądz taki nie znalazłby nabywców. Stwierdził on, że: „pieniądza nie można stworzyć z niczego, w wyniku umowy społecznej". Idea przedstawiona przez F.A. von Hayeka, jest więc sprzeczna $z$ teorematem regresji.

\subsection{Teoremat regresji a waluty wirtualne}

Według EBC (2012, s. 22), bitcoin nie spełnia teorematu regresji, gdyż nie ma wartości sam w sobie. Na tę opinię powołuje się wielu ekonomistów, kończąc tym samym swoje rozważania dotyczące uznania bitcoina za pieniądz (Douma, 2016, s. 7; Malekzadeh, 2015). Ze stwierdzeniem EBC próbowała polemizować M.L. Pattison (2011, s. 16), jednakże skutkiem jej wnikliwej analizy było stwierdzenie, że bitcoin, w świetle austriackiej szkoły ekonomii, nie jest pieniądzem. Uznała ona, że: „bitcoin nie bazuje na żadnym towarze, więc nie może obecnie mieć wartości wymiennej".
Mimo uznania bitcoina za niespełniającego teorematu regresji, niektórzy ekonomiści podejmują próby uzasadnienia słuszności nazywania go pieniądzem. Podkreśla się, że teoremat regresji dotyczy wyłącznie pieniądza, który wyewoluowal z gospodarki barterowej. Bitcoin, a szerzej waluty wirtualne, to twory nowe, do których teoremat nie ma zastosowania (Sieroń, 2013, s. 43; Davidson i Block, 2015 s. 330). L. Davidson i W. Block (2015 s. 323), uznali ponadto, że środek wymiany może powstać w dwojaki sposób:

- w gospodarce barterowej i wtedy musi mieć również wartość niepieniężną;

- w już istniejącym systemie pieniężnym.

Natomiast A. Sieron (2013, s. 44), stwierdził, że bitcoin nie narusza teorematu regresji, gdyż jest on wymienialny na inne waluty, np. dolara amerykańskiego, które kiedyś były wymienialne na złoto. Można więc prześledzić siłę nabywczą bitcoina cofając się początkowo do banknotów, potem do banknotów wymienialnych na złoto itd. Podobnie uważają M. Benedykt (2012), A. Koening (2016), I.A. Olafsson (2014, s. 40) oraz D. Schlichter (2012). M. Benedykt (2012), podaje jeszcze inne rozwiązanie problemu. Jeśli uzna się, że bitcoin nie jest pieniądzem, a jedynie środkiem wymiany, nie ma potrzeby rozpatrywania go w ramach teorematu regresji. W. Block (2013), natomiast wyjaśnia, że o ile współcześnie bitcoin nie spełnia teorematu regresji i nie jest pieniądzem, to jednak reprezentuje jakąś wartość (cenę wyrażoną w innych walutach). W przyszłości, gdy stanie się pieniądzem, fakt, że obecnie posiada jakąś wartość, spowoduje, że teoremat regresji nie będzie naruszony. $\mathrm{P}$. Surda $(2014$, s. 3), podaje przykład $z$ historii bitcoina, który początkowo był wymieniany na dolara amerykańskiego, a więc miał cenę (jak towar) i wartość wymienną.

Niektórzy ekonomiści uważają, że wartość niepieniężną bitcoina stanowiła chęć jego twórców i pierwszych użytkowników do uczestnictwa $w$ projekcie pod tą samą nazwą (Benedykt, 2012). Inni, zwracają też uwagę na koszty poniesione $w$ związku ze stworzeniem bitcoina (Olafsson, 2014, s. 40). Poruszana jest też kwestia samego systemu in- 
formatyczno-kryptograficznego i technologii, dzięki którym istnienie tej kryptowaluty oraz możliwość przesyłania za jej pomocą pewnych danych, jest w ogóle możliwe (Wiśniewska, 2016, s. 23). Na możliwość transferu środków, jako wartości niepieniężnej, zwrócił też uwagę D. Schlichter (2012).

Wspomniany P. Surda (2014, ss. 6-9), zwrócił uwagę na pomijanie przez ekonomistów problemu płynności bitcoina i oderwaniu niejako ich analiz dotyczących teorematu regresji od tego problemu, przy jednoczesnym skupieniu się na poszukiwaniu wartości niepieniężnej. Jego zdaniem, bitcoin jest dobrem płynnym, a więc może stać się pieniądzem, ale określanie go tym mianem nie jest zasadne.

\section{Metody}

W artykule zdecydowano się na zastosowanie metody studium przypadku. Badaniem objęto trzy kryptowaluty: bitcoin, ether oraz factoid. Dobór kryptowalut do badania uwzględniał ich pozycję rynkową, zgodnie $z$ danymi $z$ portalu CoinMarketCap (2017), oraz projekty, które reprezentują. Przyjęto założenie, że kryptowaluty, które powstają w ramach projektów, których nie były bezpośrednim celem, mają większe szanse na posiadanie wartości niepieniężnej niż te, których wykreowanie było głównym celem projektu, tzn. takich, które miały za zadanie stać się pieniądzem.

Określenie wartości niepieniężnej poszczególnych walut wirtualnych jest narażone na subiektywizm. Ponadto, metoda studium przypadku nie pozwala na zastosowanie uogólnień do wszystkich, alternatywnych kryptowalut, których, jak wspomniano w Sekcji 2., jest ponad 700. Problemy te, stanowią główne ograniczenie zastosowanej metody badawczej.

Studium przypadku oparto o informacje ze stron internetowych projektów, portali dedykowanych kryptowalutom oraz dostępnej literaturze przedmiotu. Zdecydowano się na skorzystanie ze źródeł internetowych, gdyz to właśnie Internet jest miejscem funkcjonowania badanych walut wirtualnych.

\section{Wyniki badania}

W Sekcji 4. przedstawiono studium przypadku bitcoina oraz dwóch kryptowalut alternatywnych. Skupiono się na zagadnieniach związanych $z$ powstaniem i funkcjonowaniem poszczególnych kryptowalut. Podjęto także próbę określenia ich wartości niepieniężnej, o ile taka istnieje, co stanowi warunek konieczny spełniania przez nie teorematu regresji.

\subsection{Bitcoin}

Idea stworzenia systemu Bitcoin powstała w październiku 2008 roku, podczas, gdy sama kryptowaluta na początku 2009 roku (Surda, 2014, s. 3). Sam autor określił system Bitcoin jako "peer-to-peer electronic cash system” (Lee i Lam, 2015, s. 11), co można przetłumaczyć jako system pieniądza elektronicznego opartego o technologię P2P. System Bitcoin umożliwia przesyłanie, za pomocą kryptowaluty bitcoin, środków finansowych w sposób natychmiastowy, tani i względnie anonimowy (Lee i Lam, 2015, ss. 12-13). Względna anonimowość (lub pseudoanonimowość) powoduje, $\dot{z}$ e bitcoin znajduje zastosowanie $\mathrm{w}$ finansowaniu działań przestępczych oraz tzw. „praniu brudnych pieniędzy".

Jako środek płatniczy, bitcoin jest akceptowany w ponad 9 tys. miejsc na całym świecie, głównie w Stanach Zjednoczonych i Europie. 14 maja 2013 roku, miejsc tych było pięćdziesiąt jeden (Coinmap, 2017). Oznacza to, że zainteresowanie tą formą płatności rośnie (wykres 1.). Zgodnie $z$ informacjami $z$ portalu CoinMarketCap (2017), cena 1 BTC 15 maja 2017 roku wynosiła około 1780 USD.

Bitcoin działa w oparciu o technologię blockchain, która znajduje zastosowanie $\mathrm{w}$ wielu dziedzinach. Są one głównie związane $z$ transferem środków finansowych, lecz technologia ta umożliwia również przesyłanie innych danych, głównie tzw. danych wrażliwych, których bezpieczeństwo jest kluczowe (np. dane medyczne, czy związane $z$ prowadzonymi badaniami naukowymi) (Forbes, 2017). Technologię tę, planuje również wyko- 
rzystać szwedzki rząd w administracji publicznej (Cryptonews, 2017).

Jak wskazano w Sekcji 2.2., problem, czy bitcoin spełnia teoremat regresji, jest dość szeroko badany, zarówno przez ekonomistów, jak i publiczne instytucje takie, jak EBC. Uwidacznia się jednak brak jednego, wspólnego podejścia do problemu.

\subsection{Ethereum}

Ethereum to zdecentralizowania platforma do prowadzenia inteligentnych kontraktów. Powstała w sierpniu 2014 roku, z inicjatywy szwajcarskiej fundacji Ethereum. Platforma umożliwia wykorzystanie technologii blockchain do tworzenia zdecentralizowanych aplikacji w dowolnym celu takim, jak (Ethereum, 2017):

- zapis ostatniej woli;

- stworzenie nowego systemu głosowania;

- założenie platformy opartej o crowfunding, która uzależnia wypłatę środków od postępów w pracach;

- stworzenie nowej kryptowaluty.

Twórca aplikacji płaci za pracę maszyny wirtualnej (za skorzystanie $z$ możliwości platformy), za pomocą tokenu zwanego ether. Im prostszy i bardziej efektywny kod, tym mniejsza ilość kryptowaluty ether jest wymagana.

Według portalu CoinMarketCap (2017), jednostka tej kryptowaluty 15 maja 2017 roku kosztowała około 92 USD. Dotychczas, ether nie znalazł zastosowania jako środek płatniczy poza platformą, stąd sensowność rozpatrywania go w kontekście teorematu regresji jest wątpliwa.

\subsection{Factom}

Projekt Factom rozpoczął się w 2014 roku, rok później powstał system Factom. Założyciele: P. Snow, B. Deery, J. Lu, D. Johnston i P. Kirby, mają na celu tworzenie i opracowywanie produktów, które uczynią świat bardziej uczciwym i przejrzystym. P. Kirby rozwiną tę myśl następująco: „założyliśmy Factom, aby zbudować uczciwszy i bardziej transparentny świat. Przyjęliśmy bardzo proste podejście: stworzyć oprogramowanie, które uniemożliwia zmianę przeszłości i skierować je tam, gdzie rozwiąże znaczące problemy biznesowe" (Factom, 2017). System wykorzystuje technologię blockchain, rozszerzając ją do wielu różnych zastosowań, związanych głównie $z$ przechowywaniem i zarządzaniem danymi przedsiębiorstw. Factom stworzył też projekt Gutenberg, dzięki któremu umieścił w łańcuchu bloków ponad 28 tys. książek (Factom, 2017).

Dotychczas, Factom (2017) zaoferowal dwa następujące produkty:

- Harmony - ułatwiający tworzenie i obieg dokumentów w przedsiębiorstwie;

- Acolyte - związany $z$ inteligentnymi kontraktami.

Kryptowalutą stworzoną przez Factom jest factoid (WeUseCoins, 2017). Umożliwia on uczestnictwo $\mathrm{w}$ projekcie, poprzez opłacenie tzw. Entry Credits, które są wykorzystywane do kupowania określonej ilości danych w sieci Factom. Entry Credits nie są transferowalne i mogą być wymieniane jedynie jednokierunkowo (Factom, 2017). Jak podkreślają twórcy projektu, system nie potrzebuje kryptowalut, aby działać.

Jak podaje portal CoinMarketCap (2017), 15 maja 2017 roku jednostka kryptowaluty factoid kosztowała 8,91 USD. Biorąc pod uwagę fakt, że factoid nie funkcjonuje jako środek wymiany poza systemem, a ponadto w samej sieci służy do zakupu tokenów, rozpatrywanie go w kontekście teorematu regresji jest zupełnie bezzasadne.

\subsection{Wnioski ze studium przypadku}

W tabeli 1. zaprezentowano syntetyczne podsumowanie przeprowadzonego studium przypadku. Spośród przeanalizowanych kryptowalut, jedynie bitcoin pełni funkcje płatniczą poza systemem, stąd zasadne jest rozważanie, czy jest pieniądzem, czy też nie. Natomiast factoid oraz ether pełnią rolę środka płatniczego jedynie $\mathrm{w}$ ramach określonego systemu, stąd też mogą być jedynie rozważane jako towary, które w przyszłości mogłyby stać się 
pieniądzem, gdyż teoremat regresji dotyczy jedynie pieniądza.

Prawdopodobną wartością niepieniężną, w przypadku bitcoina, jest możliwość przesyłania, za jego pomocą (a dokładniej za pomocą blockchain), określonych danych, które w pewnym momencie staną się (lub już się stały) pieniądzem.

Kryptowaluta ether natomiast umożliwia skorzystanie $z$ usług oferowanych przez platformę i uczestnictwo w projekcie. Reprezentuje więc chęci uczestników do dołączenia do Ethereum.

Określenie wartości niepieniężnej kryptowaluty factoid jest niemożliwe. Służy ona bowiem do opłacenia w systemie kolejnego tokenu, przy czym nie jest jedyną metodą nabycia Entry Credits. Twórcy projektu Factom podkreślają, że żadna kryptowaluta nie jest potrzebna do skorzystania $z$ systemu. Trudno więc uznać, że factoid ma wartość niepieniężną. Oczywiście, factoid może być swobodnie sprzedawany i kupowany na giełdach walut wirtualnych, więc można go uznać za dobro spekulacyjne, które ma określoną cenę. Jednak, rozpatrywanie dobra spekulacyjnego $w$ kontekście teorematu regresji jest zupełnie nieuzasadnione, gdyż mało prawdopodobne jest to, by tego rodzaju dobro mogło stać się kiedyś pieniądzem.

\section{Zakończenie}

Jedną z przeszkód $w$ uznaniu przez ekonomistów waluty bitcoin za pieniądz, jest problem rzekomego niespełniania przezeń teorematu regresji. Przeprowadzona analiza literatury oraz studium przypadku wykazały, że wartość niepieniężną bitcoina można określić na różne sposoby. Teoremat regresji nie precyzuje tego, co stanowi wartość niepieniężną. Ponadto, dane dobro, $w$ momencie pełnienia funkcji pieniądza, nie musi mieć tylko jednego zastosowania niepieniężnego. Biorąc to pod uwagę, można stwierdzić, że mnogość rozwiązań zaproponowanych przez ekonomistów tylko potwierdza, że bitcoin nie narusza teorematu regresji.
W przypadku pozostałych walut wirtualnych, trudno jest rozstrzygnąć problem jednoznacznie, zwłaszcza, gdy dana kryptowaluta nie pełni funkcji płatniczej poza systemem, w którym powstała. Nie zawsze jest możliwe i zasadne poszukiwanie wartości niepieniężnej takiej waluty wirtualnej.

\section{Bibliografia}

Benedykt, M. (2012). We Frankfurcie się nudza, więc czytają. Pobrane 09.05.2017 z http://kryzys. mises.pl.

Block, W. (2013). Regression theorem and Bitcoin. Pobrane 09.05.2017 $\mathrm{zhttps://mises.org.}$

Coinmap. (2017). Pobrane 15.05.2017 z https://coinmap.org.

CoinMarketCap. (2017). Pobrane 15.05.2017 z https://coinmarketcap.com.

Cryptonews. (2017). Pobrane 15.05.2017 z https:// cryptonews.pl.

Davidson, L., i Block, W.E. (2015). Bitcoin, the regression theorem, and the emergence of a new medium of exchange. Quarterly Journal of Austrian Economics, 18(3).

Douma, S. (2016). Bitcoin: the pros and cons of regulation. Pobrane 09.05.2017 z https://openaccess. leidenuniv.nl.

EBC. (2012). Virtual currency schemes. Pobrane 09.05.2017 z http://www.ecb.europa.eu.

Ethereum. (2017). Pobrane 15.05.2017 z https:// www.ethereum.org.

Factom. (2017). Pobrane 15.05.2017 z https://www. factom.com.

FATF. (2014). Virtual currencies. Key definitions and potential AML/CFT Risks. Pobrane 18.02.2015 $z$ http://www.fatf-gafi.org.

Forbes. (2017). Technologia blockchain może zrewolucjonizować tradycyjne systemy ptatnicze. Pobrane 15.05.2017 z http://www.forbes.pl.

Koening, A. (2016). A Beginners Guide to Bitcoin and Austrian Economics. Munchen: FinanzBuch Verlag.

Lee, D.K.C., i Lam, P.N. (2015). Introduction to bitcoin. W: D.K.C. Lee (red.), Handbook of digital currency. Bitcoin, innovation, financial instruments and big data. San Diego: Academic Press. doi:10.1016/B978-0-12-802117-0.00001-1.

Malekzadeh, A.R. (2015). Should fiat money be replaced with virtual currencies? Pobrane 09.05.2017 zhttp://www.e-ir.info.

Mises, L. von (1954). The theory of money and credit. New Haven: Yale University Press. 
Olafsson, I.A. (2014). Is Bitcoin money? An analysis from the Austrian school of economic thought. Pobrane 09.05.2017 z http://skemman.is.

Pattison, M.L. (2011). Buying into Bitcoin: An Austrian analysis of the virtual currency's sustainability. Pobrane 09.05.2017 z http://www2.gcc. edu.

Rothbard, M.N. (2011). Argumenty za prawdziwym złotym dolarem. W: L. Rockwell (red.), Austriacy o standardzie złota. Warszawa: Instytut Ludwiga von Misesa.

Schlichter, D. (2012). The death of banks - and the future of money. Pobrane 09.05.2017 $\mathrm{z}$ http:// www.goldmadesimplenews.com.
Sieroń, A. (2013). Czym jest Bitcoin? Ekonomia Wroclaw Economic Review, 19(4).

Surda, P. (2014). The origin, classification and utility of Bitcoin. doi:10.2139/ssrn.2436823.

WeUseCoins. (2017). What is Factom? Pobrane 15.05.2017 z https://www.weusecoins.com.

Wiśniewska, A. (2016). Bitcoin as an example of virtual currency. Institute of Economic Research Working Papers, 1.

Informacje uzupełniające

Wkład autorski: autor zaakceptował ostateczną wersję artykułu. 
Aneks

Tabela 1.

Porównanie kryptowalut bitcoin, ether i factoid

\begin{tabular}{|c|c|c|c|}
\hline Wyszczególnienie & Bitcoin & Ether & Factoid \\
\hline rok powstania & 2009 & 2014 & 2015 \\
\hline cel projektu & $\begin{array}{l}\text { system transferowania } \\
\text { środków finansowych }\end{array}$ & $\begin{array}{l}\text { platforma do tworzenia zde- } \\
\text { centralizowanych aplikacji }\end{array}$ & $\begin{array}{c}\text { rozwiązania blockchain dla } \\
\text { przedsiębiorstw }\end{array}$ \\
\hline $\begin{array}{c}\text { rola kryptowaluty w pro- } \\
\text { jekcie }\end{array}$ & jednostka przesyłowa & $\begin{array}{c}\text { token umożliwiający } \\
\text { opłacenie pracy maszyny } \\
\text { wirtualnej }\end{array}$ & $\begin{array}{l}\text { kupno Entry Credits umoż- } \\
\text { liwiających uczestnictwo } \\
\text { w projekcie }\end{array}$ \\
\hline $\begin{array}{l}\text { spełnianie funkcji płatniczej } \\
\text { poza systemem }\end{array}$ & tak & nie & nie \\
\hline $\begin{array}{c}\text { prawdopodobna wartość } \\
\text { niepieniężna }\end{array}$ & $\begin{array}{c}\text { możliwość przesyłania } \\
\text { danych }\end{array}$ & $\begin{array}{c}\text { korzystanie z możliwości } \\
\text { platformy }\end{array}$ & brak \\
\hline
\end{tabular}

Źródło: Opracowanie własne.

Wykres 1.

Liczba miejsc akceptujących bitcoin jako formę płatności w latach 2013-2017 (w szt.)

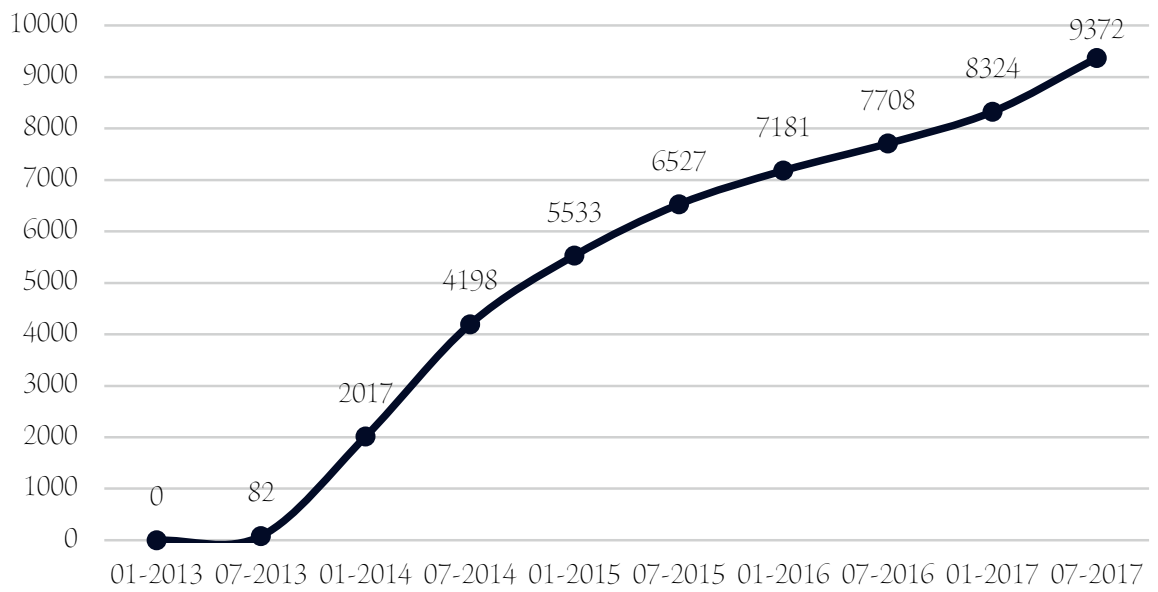

Źródło: Opracowanie własne na podstawie Coinmap (2017).

Virtual currencies in the context of the Ludwig von Mises regression theorem

\begin{abstract}
Motivation: The dynamic development of the virtual currencies market, initiated by the creation of bitcoin, poses many challenges for economic theoreticians. One of the problems explored by them is the issue of fulfilment of the $\mathrm{L}$. von Mises regression theorem by virtual currencies. The problem is the main obstacle to consider a particular virtual currency as money. Previous studies in this field focused almost entirely on bitcoin and merely signalled this problem among other considerations.

Aim: The aim of the article is to answer the question whether and to what extent virtual currencies meet the L. von Mises regression theorem.
\end{abstract}


Results: In the article it is assumed that those cryptocurrencies, which were not the direct target of the projects in which they were created, are more likely to have a non-monetary value than those, whose creation was the main aim of the project, i.e. those that were particularly designed to become money. The case study of the three virtual currencies: bitcoin, ether and factoid indicated that the designation of a non-monetary value of a particular virtual currency is not always possible and justified. In the case of bitcoin it can be stated that it does not violate the regression theorem, and has many non-monetary features. The other two cryptocurrencies, as yet, do not perform a payment function outside the project, under which they were created.

Keywords: bitcoin; virtual currencies; regression theorem

JEL: B13; E49; G19 
